\title{
The Position of Private University Lecturer on Work Termination
}

\author{
Sopian $^{1}$, Faisal Santiago ${ }^{2}$ \\ Student at Doctoral of Law, Universitas Borobudur Jakarta \\ \{sopianunborr@gmail.com¹, faisalsantiago@borobudur.ac.id²\}
}

\begin{abstract}
Lecturers are professional educators and scientists with the main task of transforming, developing, and disseminating science, technology, and arts through education, research, and community service. Lecturers are those who work with the status of teaching staff in higher education units. A higher education unit is an education service group that provides education at the higher education level, in the form of a university. Higher education is divided into State Universities (PTN) and Private Universities (PTS). Based on the higher education legislation, PTS is established by the community by forming a non-profit legal entity that is obliged to obtain a permit from the Minister. One of the organizing bodies can be in the form of a foundation. Based on these provisions, the legal relationship that occurs in PTS is between PTS lecturers and the foundation as the PTS organizing body. A foundation as a legal entity in the management of employment is included as a business entity such as a company. Therefore, when a PTS lecturer experiences layoffs, the arrangements are subject to labor legislation. The provisions governing lecturers as professional educators are regulated in Law Number 20 of 2003 concerning the National Education System, Law Number 14 of 2005 concerning Teachers and Lecturers, Law Number 12 of 2012 concerning Higher Education, Government Regulation Number 37 of 2009 concerning Lecturers. Meanwhile, the position of a lecturer in the context of being a worker/laborer has rights as the rights of laid-off workers as regulated in Law Number 13 of 2003 concerning Manpower, and Law Number 2 of 2004 concerning Settlement of Industrial Relations Disputes. This study aims to determine the position of private university lecturers for termination of employment. This research is normative legal research using a statutory and conceptual approach.
\end{abstract}

Keywords: Lecturers; University; Work Termination

\section{Introduction}

Law Number 20 of 2003 concerning the National Education System states that educators are professionals. Therefore, lecturers as professional educators have a very strategic function, role, and position. Lecturers as professionals have a vision for the realization of the implementation of learning under the principles of professionalism to fulfill the same rights for every citizen in obtaining a quality education. 
Law Number 14 of 2005 concerning Teachers and Lecturers, Article 1 point 2 affirms that "lecturers are professional educators and scientists with the main task of transforming, developing and disseminating science, technology, and arts through education, research, and community service".

Lecturers are those who work with the status of teaching staff in higher education units. A higher education unit is an education service group that provides education at the higher education level, in the form of a university. This college is divided into State Universities (PTN) and Private Universities (PTS). Based on Law Number 12 of 2012 concerning Higher Education, PTS was established by the community by forming a non-profit legal entity that was obliged to obtain permission from the Minister. Organizing bodies may take the form of foundations, associations, and other forms under the provisions of laws and regulations [1].

In general, as stipulated in Government Regulation Number 37 of 2009 concerning Lecturers, the position of the rights and obligations of both PTN and PTS lecturers is the same. The government gives the same rights and obligations to these two lecturer statuses. The obligation for all lecturers to perform the Tri Dharma of Higher Education. Private lecturers are required to have a National Lecturer Identification Number (NIDN), private lecturers are also required to apply for a rank equivalent to PNS lecturers and are required to take the highest level of education. Various competition schemes from the Government "flatter" all lecturers, for example, scholarship assistance, all lecturers, both private and public, have the same opportunity, the competition scheme for research and community service funds is the same, which only differentiates the higher education clusters.

Finally, the opportunity for private lecturers to gain government appreciation for lecturer performance is to get a Lecturer Certification who is also entitled to professional allowances according to rank and length of service. The government also provides the title of Professor or professor for qualified private lecturers to get it. From the above equation, the difference revolves around the issue of employment status only. Especially the position of PTS lecturers for employment termination (PHK). This is because the organizing body, which is usually a foundation, is categorized as a company or business entity, so that the provisions regarding employment refer to Law Number 13 of 2003 concerning Manpower, including if the PTS lecturer is subjected to layoffs by the organizing agency.

Please note that the stipulations governing lecturers as professional educators are regulated in Law Number 20 of 2003 concerning the National Education System, Law Number 14 of 2005 concerning Teachers and Lecturers, Law Number 12 of 2012 concerning Higher Education, Government Regulations Number 37 of 2009 concerning Lecturers. While the position of lecturers in the context of being workers who have rights, which are the rights of workers who have been laid off are regulated in Law Number 13 of 2003 concerning Manpower, and Law Number 2 of 2004 concerning Settlement of Industrial Relations Disputes.

Based on the background above, the position of PTS lecturers on employment termination is important. It is crucial to research more focused and deeply from the perspective of legal science in the form of the position of private university lecturers for termination of employment. Evaluating the status of private university lecturers for employment termination based on the perspective of the legislation that relevant to this research.

\section{Research Problem}


Based on the background described above, the formulation of this research problem can be formulated as follows: What is the position of lecturers from private universities on work termination?

\section{Methodology}

Based on scientific disciplines, this research is legal research. Legal research is a scientific activity, which is based on methods, systematics, and certain thoughts, which intend to examine one or several phenomena of certain laws, by analyzing them [2]. This research is normative legal research. Normative research is often called doctrinal research, which is research whose object is legal documents and library materials [3]. Bahder Johan Nasution stated that normative legal research is in the form of an inventory of applicable laws, seeking to find principles or philosophical basis of these laws, or research in the form of legal discovery efforts that are suitable for a particular case [4].

\section{Result and Discussion}

According to Law Number 14 of 2005 concerning Teachers and Lecturers, Article 1 point 2, states "Lecturers are professional educators and scientists with the main task of transforming, developing and disseminating science, technology, and arts through education, research, and community service."

According to Government Regulation Number 37 of 2009 concerning Lecturers, Article 1 point 1 states "Lecturers are professional educators and scientists with the main task of transforming, developing and disseminating science, technology, and arts through education, research, and community service".

The main duty of a lecturer is as an educator. As educators, lecturers have the duty and responsibility to educate students to become individuals who have abilities and skills that are useful for their lives and are needed to enter the world of work, through their ability to teach various knowledge and skills, in addition to responsibility in the form of correct attitudes and behaviors and is not right in acting through his exemplary character as a moral human being.

Law Number 14 of 2005, explains that Lecturers have a position as professional staff at the higher education level who are appointed under statutory regulations. The recognition of the lecturer's position as a professional is evidenced by an educator certificate [5]. The position of lecturers as professionals serves to increase the dignity and role of lecturers as agents of learning, developers of science, technology, and arts, as well as community service to improve the quality of national education [6]. Furthermore, the same law states that the position of lecturers as professionals is aimed at implementing the national education system and realizing the goals of national education, namely the development of the potential of students to become human beings who believe and fear God Almighty, have a noble character, are healthy, knowledgeable, competent, creative, independent, and become a democratic and responsible citizen [7].

Besides, Lecturers must have academic qualifications, competencies, educator certificates, are physically and mentally healthy, and meet other qualifications required by the higher education unit in which they work, and able to realize the goals of national education [8]. The status of lecturers consists of permanent lecturers and non-permanent lecturers [9]. It has been explained above that lecturers have a position as professional staff at the higher education level who are appointed under statutory regulations. Specific arrangements are contained in Government Regulation Number 37 of 2009 concerning Lecturers. However, the problem here 
is regarding the employment status of PTS lecturers when they are laid off by the foundation as the organizing body for PTS.

According to Law Number 13 of 2003 concerning Manpower, Article 1 point 25, what is meant by "employment termination is the termination of a working relationship due to certain matters resulting in the termination of rights and obligations between workers/laborers and entrepreneurs".

The provisions concerning Private Higher Education (PTS) are regulated in Law Number 12 of 2012 concerning Higher Education, which states that Private Universities, hereinafter referred to as PTS, are tertiary institutions established and/or operated by the community [10]. PTS was established by the community by forming a legal entity with non-profit principles [11]. Higher education is a higher education unit which according to Government Regulation Number 37 of 2009 concerning Lecturers is an educational service group that organizes education at the higher education level [12]. The higher education unit includes higher education units organized by the Government, and higher education units organized by the community [13].

Organizing bodies in higher education units are usually run by foundations, which are legal entities with non-profit principles. Based on these provisions, the legal relationship that occurs in PTS is between PTS lecturers and foundations. In the General Elucidation of Law Number 14 of 2005, it is stated that the position of teachers and lecturers as professionals is part of the reform of the national education system whose implementation takes into account various provisions of laws and regulations in the fields of education, expertise, employment, finance, and regional government [14]. Based on the general explanation above, the legal relationship between lecturers and foundations in the implementation of work is a working relationship that is subject to Law Number 13 of 2003 concerning Manpower. Likewise, when a lecturer is dismissed by the foundation as the organizing body for PTS, the regulation refers to Law Number 13 of 2003 concerning Manpower.

According to F.X. Djumialdji, termination of employment is the termination of a working relationship due to certain things that result in the termination of rights and obligations between workers or laborers and employers [15]. Meanwhile, Nurachmad interpreted that termination of employment was the termination of a certain work relationship which resulted in the termination of rights and obligations between workers and employers [16]. Furthermore, according to D. Danny H. Simanjuntak, termination of employment is the termination of employment relations between employers or employers and employees, which is caused by several important factors [17].

According to Law Number 13 of 2003 concerning Manpower, Article 1 point 25 that what is meant by "termination of employment is the termination of the employment relationship due to certain matters resulting in the termination of rights and obligations between workers/labor and entrepreneurs".

Law Number 13 of 2003 concerning Manpower, Article 150 states "the provisions regarding termination of employment in this Law include termination of employment that occurs in a business entity that is a legal entity or not, is owned by individuals, belongs to a partnership or belongs to a legal entity, either private and state-owned, as well as social enterprises and other businesses that have management and employ other people by paying wages or other forms of compensation."

Since a foundation as a legal entity that organizes PTS is categorized the same as a legal entity, the position of a lecturer based on Law No. 13 of 2003 is as an employee. In the context of employment, an employee is anyone who works and receives wages or other forms of remuneration [18]. Meanwhile, an employment relationship is a relationship between an 
entrepreneur and a worker/laborer based on a work agreement, which has elements of work, wages, and orders [19].

In the perspective of employment, a working relationship is a legal relationship carried out by at least two legal subjects regarding a duty [20]. Legal subjects who carry out an employment relationship are entrepreneurs/employers and workers/laborers. Employment relations are at the core of industrial relations [21]. A relationship between a worker and an employer, where the working relationship occurs after an employment agreement exists between the two parties. They are bound by an agreement, on the one hand, the worker/laborer is willing to work for a wage and the entrepreneur hires the worker/laborer for a wage [22].

According to Government Regulation Number 37 of 2009 concerning Lecturers, Article 1 point 9, what is meant by "a work agreement or collective work agreement is a written agreement between lecturers and providers of higher education or higher education units which contains the conditions of work and the rights and obligations of the parties. the principle of equality and serviceability based on statutory regulations". In this context, higher education providers or private higher education units are foundations that are legal entities regulated by Law Number 28 of 2004 concerning Amendments to Law Number 16 of 2001 concerning Foundations.

Meanwhile, according to Law Number 13 of 2003, Article 1 point 14, "a work agreement is an agreement between a worker/laborer and an entrepreneur or employer that contains the terms of employment, rights, and obligations of the parties". Meanwhile, according to Subekti, a work agreement is an agreement in which the first party, the worker, binds himself to work and receives wages on the other party, the employer, who tied himself to work on the worker by paying wages [23]. Based on the provisions of Article 51 paragraphs (1) and (2) of the same law, it is stated that work agreements are made in writing or orally. Work agreements that are required in writing are carried out by the prevailing laws and regulations.

A work agreement is evidence of a legal bond that regulates and creates rights and obligations. Regarding the agreement according to R. Wirjono Prodjodikoro [24]:

“... The agreement remains a legal relationship between a person and a person, more strictly between a certain person and certain other people. This means that BW law still views an agreement as a legal relationship in which a certain person, based on a promise, is obliged to do something, and certain other people have the right to demand the implementation of that obligation."

An agreement can be born because of the various obligations or achievements that must be fulfilled. Not only the performance that has been determined must be fulfilled by one of the parties in the agreement, but also the performance that is determined by law, and performed on a reciprocal basis, between the two parties in the agreement. Based on the construction, it is clear that the agreement is a source of an alliance. Thus, the employment agreement between PTS lecturers and the Foundation as the organizing body of PTS is a legal relationship and source of the alliance, so in the context of layoffs of lecturers as workers/workers of the Foundation whose legal body is subject to labor laws.

Regarding the appointment of private lecturers in Law No. 14 of 2005, it is stated that the appointment and placement of lecturers in higher education units organized by the community are carried out by the education provider or higher education unit concerned based on a work agreement or collective work agreement [25]. Likewise, in Law Number 12 of 2012, the appointment and placement of lecturers by the organizing body are carried out based on a work agreement or work agreement under the provisions of the legislation [26]. The administering body provides basic salaries and allowances to lecturers following statutory provisions [27]. The work agreement or work agreement contains the basic salary, income 
attached to the salary, other income, and social welfare security as well as additional benefits under the law that governs lecturers [28].

Although the setting of lecturers as professional educators is very clear and firm as in Law Number 20 of 2003 and Law No. 14 of 2005, however, if you take into account the provisions on the procedure of appointment, placement, and employment for lecturers appointed by the education unit organized by the community (private lecturers) are done based on work agreements or joint work agreements. This indicates that the working relationship between the lecturer and the organizing body or education unit is a normal working relationship without privilege as the working relationship in Law No. 13 of 2003.

It should be noted that the substance of Law No. 13 of 2003 explicitly states the types of businesses, such as foundations and educational institutions, are included in the definition of companies and entrepreneurs.

Based on the explanation above, it can be seen that the working relationship between lecturers and foundations in carrying out work and in terminating employment is subject to Law Number 13 of 2003 concerning Manpower. Because the status of a lecturer in the context of employment is as a worker, then in terms of termination of employment it refers to Law Number 13 of 2003 and if a dispute occurs in termination of employment, it is resolved based on Law Number 2 of 2004 concerning Settlement of Industrial Relations Disputes.

However, it should be noted that the termination of employment for lecturers as professional educators is also regulated in Law Number 14 of 2005 concerning Teachers and Lecturers. Employment termination by foundations or private higher education institutions against lecturers as workers, if linked to Law Number 14 of 2005 concerning Teachers and Lecturers as regulated in Article 67, which states:

a. Lecturers can be honorably dismissed from their positions as lecturers because:

1. Die;

2. Reached the retirement age limit;

3. At his own request;

4. Unable to carry out tasks continuously for 12 (twelve) months because of physical and/or mental illness; or

5. The end of the work agreement or. Collective working agreement between lecturers and education providers.

b. Lecturers can be dishonorably dismissed from their positions as lecturers because:

1. Violate the oath and promise of the department;

2. Violate work agreements or joint work agreements; or

3. Neglecting obligations in carrying out duties for 1 (one) month or more continuously.

c. The dismissal of lecturers as referred to paragraph (1) and paragraph (2) shall be carried out by the education provider or higher education unit concerned based on statutory regulations.

Dismissal of lecturers can be carried out after the lecturer is allowed to defend himself. Lecturers in higher education units run by the community who are dismissed with respect, not at their request receive financial compensation under work agreements or collective labor agreements [29]. However, this provision is considered to be biased, directed more towards civil servant lecturers, and tends not to be used by the Foundation as the organizing body for PTS. Foundations in this case tend to use labor laws in regulating processing layoffs of lecturers who work for private universities under the auspices of their foundation. This is also used in settling layoff disputes. 


\section{Conclusion and Suggestion}

\subsection{Conclusion}

Based on the above discussion, it can be seen that until now there has been no legal certainty regarding the status and position of PTS lecturers as professional educators or as workers/laborers when there is a termination of employment. Although the termination of employment for lecturers has been regulated in Law Number 14 of 2005 concerning Teachers and Lecturers, the regulation is still biased. In fact, the foundation as an organizing body uses the provisions stipulated by Law Number 13 of 2003 concerning Manpower. In the context of employment, the position of private university lecturers as professional educators is equated with workers/laborers. Here there is confusion regarding legal certainty due to different arrangements in the settlement of PTS lecturers' termination of employment, which should refer to legislation in the field of education.

\subsection{Suggestion}

The occurrence of legal uncertainty occurs when it is related to regulations regarding private lecturers whether their position is as a professional or as a worker/laborer. For this reason, new legislation is needed that strictly regulates the status and position of PTS lecturers as professional educators in terminating relationships, to provide legal certainty for the position of PTS lecturers as professional educators in the field of education. This is intended as a form of legal certainty for PTS lecturers for the common good so that no party is harmed.

\section{References}

[1] Undang-Undang Republik Indonesia Nomor 12 Tahun 2012 tentang Pendidikan Tinggi.

[2] Soekanto, Soerjono.: Pengantar Penelitian Hukum. Universitas Indonesia, Jakarta (2006).

[3] Soejono dan H. Abdurahman.: Metode Penelitian Hukum. Rineka Cipta Jakarta (2003).

[4] Nasution, Bahder Johan.: Metode Penelitian Ilmu Hukum. Mandar Maju, Bandung (2008).

[5] Undang-Undang Republik Indonesia Nomor 14 Tahun 2005 tentang Guru dan Dosen.

[6] Undang-Undang Republik Indonesia Nomor 14 Tahun 2005 tentang Guru dan Dosen.

[7] Undang-Undang Republik Indonesia Nomor 14 Tahun 2005 tentang Guru dan Dosen.

[8] Undang-Undang Republik Indonesia Nomor 14 Tahun 2005 tentang Guru dan Dosen.

[9] Undang-Undang Republik Indonesia Nomor 14 Tahun 2005 tentang Guru dan Dosen.

[10] Undang-Undang Republik Indonesia Nomor 12 Tahun 2012 tentang Pendidikan Tinggi.

[11] Undang-Undang Republik Indonesia Nomor 12 Tahun 2012 tentang Pendidikan Tinggi.

[12] Peraturan Pemerintah Republik Indonesia Nomor 37 Tahun 2009 tentang Dosen.

[13] Peraturan Pemerintah Republik Indonesia Nomor 37 Tahun 2009 tentang Dosen.

[14] Undang-Undang Republik Indonesia Nomor 14 Tahun 2005 tentang Guru dan Dosen. 
[15] Djumialdji, F.X.: Perjanjian Kerja. Cet. Ke-1, Sinar Grafika, Jakarta (2005).

[16] Nurachmad, Much.: Cara Menghitung Upah Pokok, Uang Lembur, Pesangon, dan Dana Pensiun. Visimedia, Jakarta (2009).

[17] Simanjuntak, D. Danny H.: PHK dan Pesangon Karyawan, Cet.Ke-1. Pustaka Yustisia, Yogyakarta (2007).

[18] Undang-Undang Republik Indonesia Nomor 13 Tahun 2003 tentang Ketenagakerjaan.

[19] Undang-Undang Republik Indonesia Nomor 13 Tahun 2003 tentang Ketenagakerjaan.

[20] Hartono, Judiantoro.: Segi Hukum Penyelesaian Perselisihan Perburuhan. Rajawali Pers, Jakarta (1992).

[21] Wijayanti, Asri.: Hukum Ketenagakerjaan Pasca Reformasi. Sinar Grafika, Jakarta (2009).

[22] Hakim, Abdul.: Pengantar Hukum Ketenagakerjaan Indonesia. Citra Aditya Bakti, Bandung (2003).

[23] Subekti, Aneka Perjanjian. Alumni, Bandung (1977).

[24] Prodjodikoro, R. Wirjono.: Azas-Azas Hukum perjanjian. Mandar Maju, Bandung (2000).

[25] Undang-Undang Republik Indonesia Nomor 14 Tahun 2005 tentang Guru dan Dosen.

[26] Undang-Undang Republik Indonesia Nomor 12 Tahun 2012 tentang Pendidikan Tinggi.

[27] Undang-Undang Republik Indonesia Nomor 12 Tahun 2012 tentang Pendidikan Tinggi.

[28] Undang-Undang Republik Indonesia Nomor 12 Tahun 2012 tentang Pendidikan Tinggi.

[29] Undang-Undang Republik Indonesia Nomor 14 Tahun 2005 tentang Guru dan Dosen. 